\begin{tabular}{ll}
\hline Homepage: $h$ htp://jusami.batan.go.id & Jurnal Sains Materi Indonesia \\
\hline & $\begin{array}{l}\text { Akreditasi LIPI } \\
\text { No.: 602/AU3/P2MI-LIPI/03/2015 } \\
\text { Tangal 15 April 2015 } \\
\text { ISSN : 1411-1098 }\end{array}$ \\
\hline
\end{tabular}

\title{
BIOSINTESIS NANOPARTIKEL PERAK MENGGUNAKAN EKSTRAK DAUN SAMBILOTO: OPTIMASI PROSES DAN KARAKTERISASI
}

\author{
Nyoman Wendri, Ni Nyoman Rupiasih dan Made Sumadiyasa \\ Jurusan Fisika, FMIPA - Universitas Udayana \\ Kampus Bukit Jimbaran, Badung, Bali 80361 \\ E-mail: rupiasih@unud.ac.id
}

Diterima: 27 February 2017

Diperbaiki: 22 Juni 2017

Disetujui: 6 Juli 2017

\begin{abstract}
ABSTRAK
BIOSINTESIS NANOPARTIKEL PERAK MENGGUNAKAN EKSTRAK DAUN SAMBILOTO: OPTIMASI PROSES DAN KARAKTERISASI. Pada penelitian ini telah berhasil disintesis nanopartikel perak (AgNP) dengan metode biologi (biosintesis). Sintesis dilakukan dengan menggunakan ekstrak daun Sambiloto (Andrographis paniculata Ness). Penelitian ini meliputi penentuan rasio volume sintesis (larutan $\mathrm{AgNO}_{3}$ :larutan ekstrak) yang optimum dan karakterisasi nanopartikel perak yang terbentuk. Konsentrasi larutan $\mathrm{AgNO}_{3}$ yang digunakan $1 \mathrm{M}$ dan larutan ekstrak adalah 7,5 g/L. Karakterisasi meliputi spektrofotometer $U V$-Vis, EDS, TEM, XRD dan FT-IR. Hasil penelitian menunjukkan bahwa rasio volume sintesis optimum adalah $10 \mu \mathrm{L}: 10 \mathrm{~mL}$. Karakteristik nanopartikel perak yang diperoleh adalah absorbsi Surface Plasmon Resonance $(S P R)$ pada panjang gelombang $423 \mathrm{~nm}$. Puncak-puncak difraksi teramati pada sudut $2 \theta$ yaitu $38,18^{0}, 45,81^{\circ}$

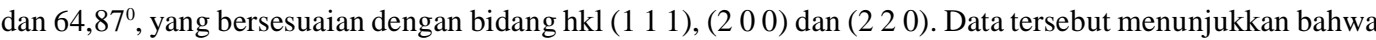
nanopartikel perak yang terbentuk memiliki struktur kristal Fface Centre Cubic $(F C C)$ dengan parameter kisi a sebesar 4,03 ̊. Hasil karakterisasi dengan TEM diperoleh ukuran partikel sekitar 10-30 nm.
\end{abstract}

Kata kunci: Nanopartikel perak, Biosintesis, Optimasi, Daun Sambiloto, SPR dan FCC

\begin{abstract}
BIOSYNTHESIS OF SILVER NANOPARTICLES USING SAMBILOTO LEAF EXTRACT: OPTIMIZATION PROCESS AND CHARACTERIZATION. It has been synthesized silver nanoparticles (AgNP) with biological method or biosynthesis, successfully. The synthesis is done using extract of Sambiloto leaf (Andrographis paniculata Ness). The study involved determining the optimum volume ratio of synthesis i.e. $\mathrm{AgNO}_{3}$ solution:extract solution and characterization of nanoparticles formed. The concentration of $\mathrm{AgNO}_{3}$ solution used was $1 \mathrm{M}$ and extract solution was $7.5 \mathrm{~g} / \mathrm{L}$. The characterization included UV-Vis spectrophotometer, EDS, TEM, XRD and FT-IR spectrophotometer. The results obtained were, the optimum volume ratio of synthesis was $10 \mu \mathrm{L}: 10 \mathrm{~mL}$. The characteristics of AgNP formed were the Surface Plasmon Resonance (SPR) absorbance at a wavelength of $423 \mathrm{~nm}$. The diffraction peaks observed at angles $2 \theta$ of $38.18^{\circ}, 45.81^{\circ}$ and $64.87^{\circ}$ which corresponded to the hkl (lll 111$),\left(\begin{array}{lll}2 & 0 & 0\end{array}\right)$ and $\left(\begin{array}{lll}2 & 2 & 0\end{array}\right)$. These results showed that the crystal structure of AgNP formed was face center cubic (FCC) with lattice parameter a, of $4.03 \AA$. TEM characterization showed that the size of AgNP nanoparticles was about 10-30 nm.
\end{abstract}

Keywords: Silver nanoparticles, Biosynthesis, Optimation, Sambiloto, SPR, FCC 


\section{PENDAHULUAN}

Saat ini telah banyak dikembangkan sintesis nanopartikel menggunakan metode biologi, yang lebih dikenal dengan metode biosintesis. Biosintesis adalah cara sintesis nanopartikel dengan menggunakan media dari bahan-bahan biologi baik mikroorganisme ataupun ekstrak dari tumbuh-tumbuhan. Penggunaan bahan ramah lingkungan tersebut memberikan manfaat terhadap keamanan lingkungan serta cocok untuk aplikasi biomedis dan farmasi, karena dalam proses sintesisnya tidak menggunakan bahan kimia beracun [1-3].

Beberapa jenis tumbuhan telah digunakan dalam biosintesis nanopartikel perak dan emas, seperti Azadirachta indica, Datura metel, Hellianthus annus, Capsicum annuum, Diospyros, Syzygium cumin, Neem dan Cissus quadrangularis [2-4]. Windri Handayani, dkk (2011) telah melaporkan delapan jenis tumbuhan yang berpotensi sebagai agent pereduksi perak serta variasi beberapa faktor yang mempengaruhi proses biosintesis tersebut. Dari delapan tanaman yang diteliti yaitu Azadirachta indica (Mimba), Centtela asiatica (Pegagan), Cerbera manghas (Bintaro), Diospyros blancai (Bisbul), Murraya paniculata (Kemunning), Pometia pinnata (Matao) dan Phalleria macrocarpa (Mahkota dewa). Tanaman Bisbul menghasilkan nanopartikel perak yang paling banyak dan dalam waktu yang paling cepat [5].

Ekstrak latek dari tanaman Thevetia peruviana, ekstrak dari daun Neem dan dari tanaman Cissus quadrangularis juga telah digunakan untuk mensintesis nanopartikel perak [2-4]. Karakteristik nanopartikel perak yang diperoleh masing-masing adalah ukuran partikel antara 10-30 nm, $43 \mathrm{~nm}$ dan $41 \mathrm{~nm}$, puncak Surface Plasmon Resonance (SPR) pada panjang gelombang $570 \mathrm{~nm}, 420 \mathrm{~nm}$ dan $421 \mathrm{~nm}$. Nanopartikel perak yang disintesis menggunakan ekstrak latek dari Thevetia peruviana memiliki struktur kristal Face Center Cubic (FCC) dengan jarak antar bidang kisi 2,35 $\mathrm{A}$, sedangkan nanopartikel perak hasil sintesis dari tanaman Cissus quadran gularis memiliki struktur cubic $[2,4]$.

Dari laporan beberapa peneliti tersebut di atas, dapat dijelaskan bahwa setiap tanaman memberikan hasil dan karakteristik nanopartikel yang berbeda. Oleh sebab itu diperlukan banyak data tentang sintesis nanopartikel dengan menggunakan berbagai jenis tanaman. Tanaman Sambiloto adalah salah satu jenis tanaman obat tradisional. Tanaman Sambiloto kaya akan senyawa polifenol seperti flavonoid, fenol dan tannin. Juga mengandung senyawa kimia lainnya seperti andrographolide, panikulida, farnesol, protein arabinogalaktan, dan saponin [6]. Senyawa polifenol adalah salah satu senyawa kimia yang diduga dapat berperan sebagai agent pereduksi [2,6]. Oleh sebab itu tanaman Sambiloto dapat digunakan untuk mensintesis nanopartikel khususnya nanopartikel perak. Juga dilaporkan proses optimasi untuk memperoleh protokol biosintesis dengan hasil optimal dan karakteristik nanopartikel perak dari hasil biosintesis tersebut.

\section{METODE PERCOBAAN}

Tahapan dalam biosintesis dan karakterisasi nanopartikel perak (AgNP) menggunakan ekstrak daun Sambiloto sebagai berikut. Pertama, dilakukan biosintesis nanopartikel perak menggunakan ekstrak daun Sambiloto untuk menemukan protokol biosintesis dengan hasil optimal. Pada tahap ini, hasil biosintesis optimal ditentukan menggunakan teknik spektrofotometer $U V$-Vis. Selanjutnya, karakterisasi perak nanopartikel menggunakan beberapa teknik diantaranya spektrofotometer $U V$-Vis, FTIR, XRD, EDS dan TEM. Dari semua tahapan tersebut diperoleh protokol biosintesis nanopartikel perak menggunakan ekstrak daun Sambiloto dan karakteristik nanopartikel perak hasil biosintesis tersebut.

\section{Ektrak Daun Sambiloto}

Tiga (3) g daun Sambiloto kering dicampur dengan $400 \mathrm{~mL}$ aqua-demineral (aqua-dm), yang dalam hal ini konsentrasinya yaitu $7,5 \mathrm{~g} / \mathrm{mL}$, kemudian dipanaskan sampai mendidih dan matikan pemanas. Diamkan ekstrak Sambiloto sampai suhu ruang, selanjutnya saring dengan kain kasa bersih. Diperoleh ekstrak Sambiloto sebesar $\pm 396 \mathrm{~mL}$ dan siap digunakan.

\section{Biosintesis}

Konsentrasi larutan $\mathrm{AgNO}_{3}$ yang digunakan adalah $1 \mathrm{M}$. Biosintesis dilakukan dengan mencampurkan ekstrak Sambiloto dengan larutan $\mathrm{AgNO}_{3}$. Amati perubahan warna campuran menjadi larutan kecoklatan. Perubahan warna tersebut merupakan satu indikasi sudah terbentuknya nanopartikel perak. Pada tahap optimasi, telah dilakukan variasi rasio volume larutan $\mathrm{AgNO}_{3}$ terhadap ekstrak Sambiloto dalam $\mu \mathrm{L}$ dan $\mathrm{mL}$, masing-masing yaitu 2:10, 5:10, 10:10, 20:10,30:10 dan 40:10. Setelah 30 menit reaksi berlangsung, kemudian dari sampel diambil untuk dilakukan pengukuran spektrofotometer $U V$-Vis.

\section{HASIL DAN PEMBAHASAN}

\section{Optimasi Proses Biosintesis}

Telah berhasil disintesis nanopartikel perak dengan metode biosintesis, menggunakan ekstrak daun Sambiloto. Perubahan warna yang teramati adalah campuran larutan $\mathrm{AgNO}_{3}$ dan ekstrak Sambiloto berubah warna dari bening menjadi warna kekuningan setelah 2 menit, kemudian berwarna kecoklatan setelah 1 jam. Warna kecoklatan bertambah pekat seiring dengan bertambahnya waktu, seperti tampak pada Gambar 1 . 


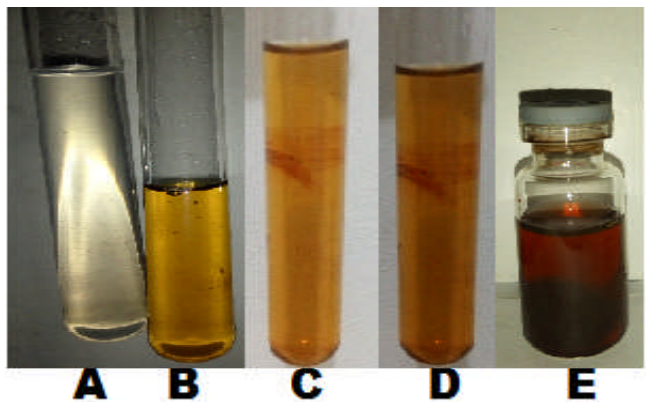

Gambar 1. (a). Larutan $\mathrm{AgNO}_{3}$ (b). Ekstrak daun Sambiloto (c,d dan e). Koloid nanopartikel perak setelah 2 menit, 1 jam dan 48 jam.

Hasil karakterisasi menggunakan spektrofotometer $U V$-Vis dari larutan $\mathrm{A}_{\mathrm{g}} \mathrm{NO}_{3}$, ekstrak Sambiloto dan koloid nanopartikel perak ditampilkan pada Gambar 2. Tampak bahwa koloid nanopartikel perak hasil biosintesis menunjukkan spektrum $U V$-Vis yang sangat berbeda dari kedua larutan (larutan $\mathrm{AgNO}_{3}$ dan larutan ekstrak Sambiloto) yaitu diperoleh puncak absorbsi pada panjang gelombang di sekitar $423 \mathrm{~nm}$ untuk waktu

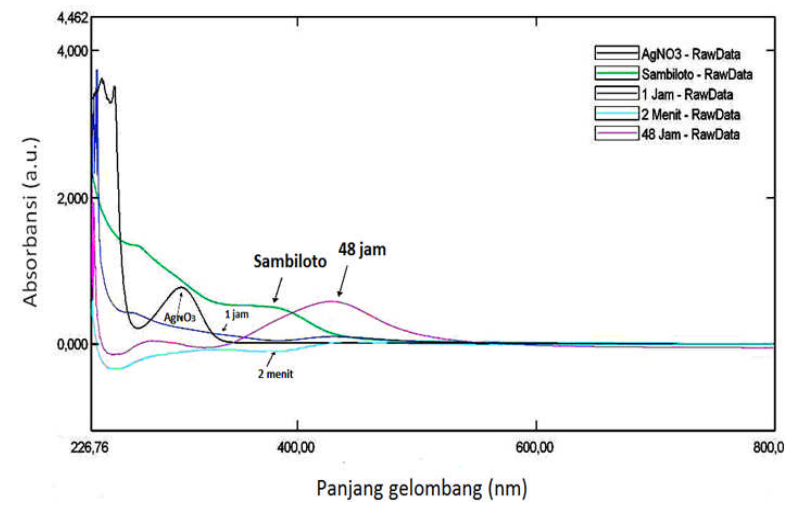

Gambar 2. Spektrum UV-Vis dari larutan $\mathrm{AgNO}_{3}$, ekstrak Sambiloto dan koloid nanopartikel perak fungsi waktu: setelah 2 menit, 1 jam dan 48 jam.

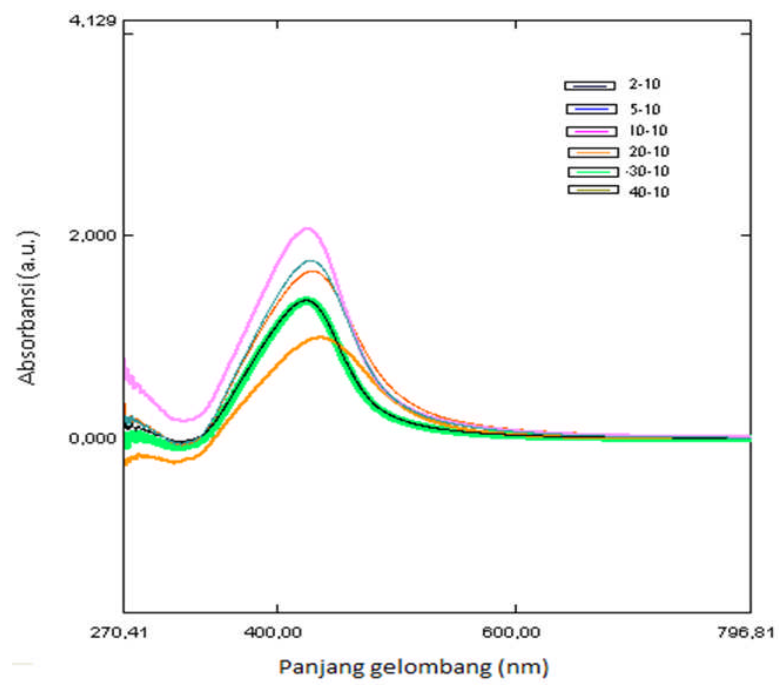

Gambar 3. Spektrum UV-Vis nanopartikel perak hasil biosintesis menggunakan ekstrak Sambiloto dengan berbagai rasio larutan $\mathrm{AgNO}_{3}$. sintesis 48 jam. Panjang gelombang tersebut merupakan karakteristik absorbsi Surface Plasmon Resonance (SPR) yang khas dari nanopartikel perak. Hasil tersebut sesuai dengan yang dilaporkan peneliti sebelumnya $[3,4,7,8]$.

Pada tahap optimasi diperoleh spektrum hasil pengukuran spektrofotometer $U V$-Vis seperti tampak pada Gambar 3. Masing-masing spektrum pada Gambar 3 memperlihatkan terbentuknya sebuah puncak absorbsi $S P R$ pada panjang gelombang di sekitar $423 \mathrm{~nm}$. Lebih tepatnya, puncak SPR dan nilai absorbsi dari masing-masing sampel dituliskan pada Tabel 1.

Tabel 1. Puncak SPR dari nanopartikel perak hasil biosintesis menggunakan ekstrak Sambiloto.

\begin{tabular}{|c|c|c|}
\hline \multirow{2}{*}{$\begin{array}{c}\text { Rasio biosintesis } \\
\text { (larutan } \mathrm{AgNO}_{3} \\
(\mu \mathrm{L}) \text { : ekstrak } \\
\text { Sambiloto }(\mathrm{mL}))\end{array}$} & \multicolumn{2}{|c|}{ Puncak SPR (surface plasmon resonance) } \\
\hline & $\begin{array}{l}\text { Panjang gelombang } \\
(\mathrm{nm})\end{array}$ & Absorbsi (a.u.) \\
\hline $2: 10$ & 428,0 & 1,654 \\
\hline $5: 10$ & 426,5 & 1,757 \\
\hline $10: 10$ & 423,5 & 2,069 \\
\hline $20: 10$ & 436,0 & 0,992 \\
\hline $30: 10$ & 423,5 & 1,362 \\
\hline $40: 10$ & 424,0 & 1,365 \\
\hline
\end{tabular}

Dari data pada Tabel 1 dapat ditentukan bahwa rasio sintesis 10:10 memberikan nilai absorbansi terbesar, untuk lama waktu sintesis sekitar 30 menit. Rasio sintesis tersebut telah memberikan hasil optimal dan digunakan pada tahap produksi nanopartikel selanjutnya.

\section{Karakterisasi Nanopartikel Perak}

\section{Karakterisasi FT-IR}

Hasil analisis kedua sampel diperlihatkan dengan label pada masing-masing spektrum dan untuk penjelasan gugus fungsi hanya ditampilkan untuk senyawa nanopartikel perak seperti dituliskan pada Tabel 2. Hasil karakterisasi FT-IR dari ekstrak Sambiloto dan senyawa nanopartikel perak hasil biosintesis menggunakan ekstrak Sambiloto diperlihatkan pada Gambar 4(a) dan Gambar 4(b).

Tabel 2. Data analisis FT-IR dari senyawa nanopartikel perak hasil biosintesis menggunakan ekstrak Sambiloto.

\begin{tabular}{llc}
\hline Puncak $\left(\mathrm{cm}^{-1}\right)$ & Gugus fungsional & Referensi \\
\hline 3464 & $\begin{array}{l}\text { OH dan N-H group pada } \\
\text { karbohidrat }\end{array}$ & {$[8,10]$} \\
2930 dan 2870 & C-H stretch dari alkanes & {$[10]$} \\
1641 & C=O stretch/ amide bending & {$[10]$} \\
1386 & N-O bending & {$[10-11]$} \\
1116 & C-O-C stretch aromatic ring & {$[10]$} \\
1100 & C-O group & {$[12]$} \\
1037 & C-N stretch dari amines & {$[11]$} \\
\hline
\end{tabular}

Dari data tersebut dapat dikatakan bahwa, hasil pengamatan ini sesuai dengan yang telah dilaporkan oleh beberapa peneliti seperti pada Tabel 2. Ada banyak gugus fungsi yang mungkin bertanggung jawab atas bioreduksi ion $\mathrm{Ag}^{+}$menjadi nanopartikel $\mathrm{Ag}$. Kesamaan 

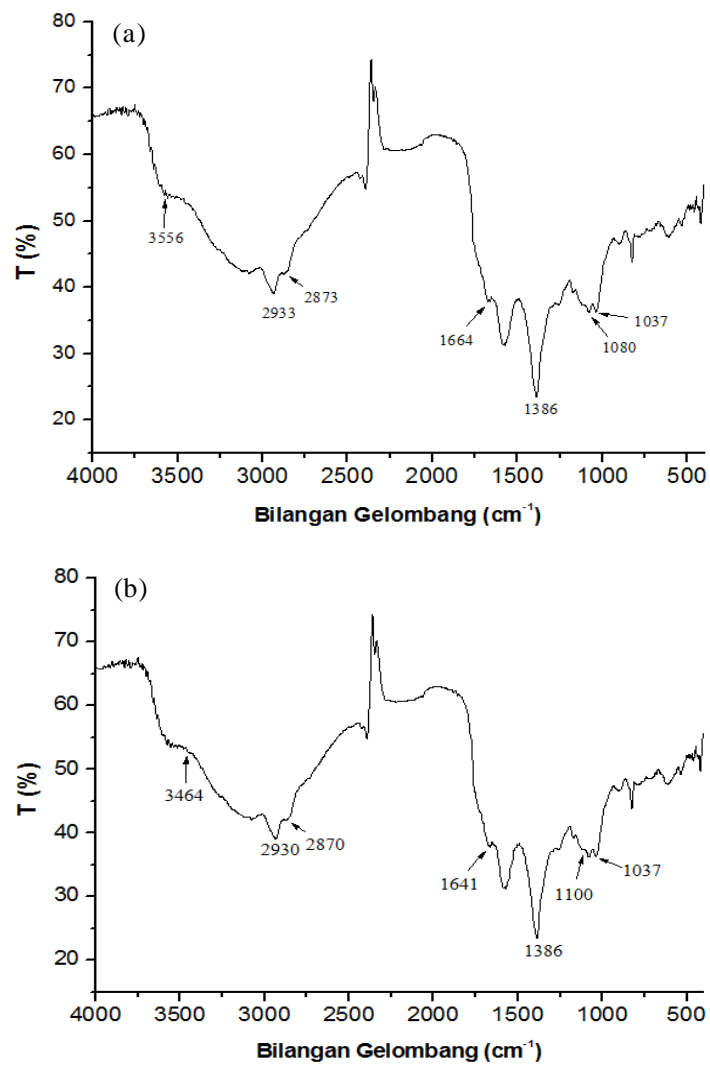

Gambar 4. (a). Spektrum FT-IR ekstrak Sambiloto, (b). Spektrum FT-IR senyawa nanopartikel perak hasil biosintesis menggunakan ekstrak Sambiloto.

antara spektrum dengan beberapa pergeseran pada posisi puncak, secara jelas menunjukkan adanya sisa dari ekstrak tanaman dalam sampel sebagai capping agent pada nanopartikel perak. Oleh sebab itu, dapat disimpulkan bahwa biomolekul tersebut bertanggung jawab sebagai capping agent dari nanopartikel yang disintesis [8,10-12].

\section{Karakterisasi $X R D$}

Dari karakterisasi XRD diperoleh grafik seperti tampak pada Gambar 5 dan analisisnya dituliskan pada Tabel 3.

Sesuai dengan data JCPDS No. 03-0921, puncak yang sesuai adalah puncak dengan sudut $2 \theta$ : $38,18^{\circ}$, $45,81^{\circ}$ dan $64,87^{\circ}$, yang masing-masing bersesuaian dengan bidang hkl: ( $\left.\begin{array}{lll}1 & 1 & 1\end{array}\right),\left(\begin{array}{lll}2 & 0 & 0\end{array}\right)$ dan (2 200$)$. Dengan demikian di dalam sampel sudah terbentuk nanopartikel perak dengan struktur Face Center Cubic (FCC). Sedangkan beberapa puncak juga tampak (Tabel 3) seperti $22,98^{\circ}, 27,34^{\circ}$ dan $31,76^{\circ}$, yang kemungkinan merupakan karakteristik senyawa lain yang berada pada senyawa nanopartikel perak hasil biosintesis tersebut.

Selanjutnya, dengan menggunakan persamaan Bragg diperoleh parameter kisi $F C C$ (a) rata-rata adalah $4,03 \AA$. Hal yang sama juga dilaporkan oleh peneliti sebelumnya [11].

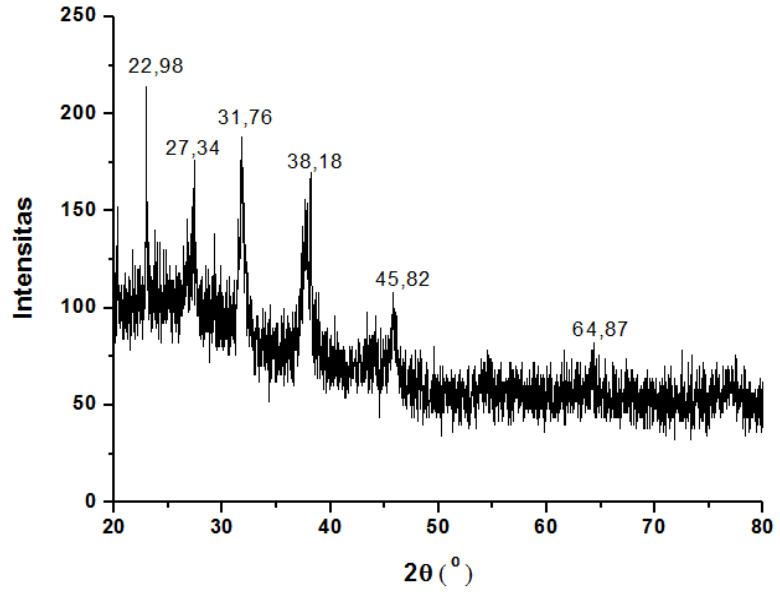

Gambar 5. Grafik XRD dari senyawa nanopartikel perak hasil biosintesis menggunakan ekstrak Sambiloto.

Tabel 3. Puncak difraksi senyawa nanopartikel perak hasil biosintesis menggunakan ekstrak Sambiloto.

\begin{tabular}{ccccc}
\hline No. & $2 \theta\left({ }^{\circ}\right)$ & Intensitas (cacah) & FWHM $\left(^{\circ}\right)$ & $\mathrm{d}(\AA)$ \\
\hline 1. & 22,98 & $71(100 \%)$ & 0,109 & 3,865 \\
2. & 27,34 & $40(56 \%)$ & 0,224 & 3,258 \\
3. & 31,76 & $58(82 \%)$ & 0,253 & 2,815 \\
4. & $38,18^{*}$ & $64(90 \%)$ & 0,222 & 2,383 \\
5. & $45,81^{*}$ & $34(48 \%)$ & 0,139 & 1,978 \\
6. & $64,87^{*}$ & $17(24 \%)$ & 0,105 & 1,436 \\
\hline
\end{tabular}

*sudut-sudut 2 yang sesuai dengan data JCPDS (Joint Committee on Power Diffraction Standard) No. 03-0921.

\section{Karakterisasi $E D S$}

Gambar 6 menunjukkan spektrum EDS dari senyawa nanopartikel perak yang disintesis. Hasil analisis tersebut menunjukkan intensitas yang tinggi di daerah perak, yaitu di puncak penyerapan optik khas yang ditunjukkan pada kira-kira $3 \mathrm{keV}$ dan mengkonfirmasikan pembentukan nanopartikel perak [11]. Juga tampak intensitas yang tinggi untuk Si, hal ini dikarenakan wafer $\mathrm{Si}$ (111) telah digunakan sebagai tempat sampel. Puncak lain juga tampak pada spektrum, yang mungkin berasal dari senyawa lain yang terkandung dalam senyawa nanopartikel perak hasil biosintesis [2,11].

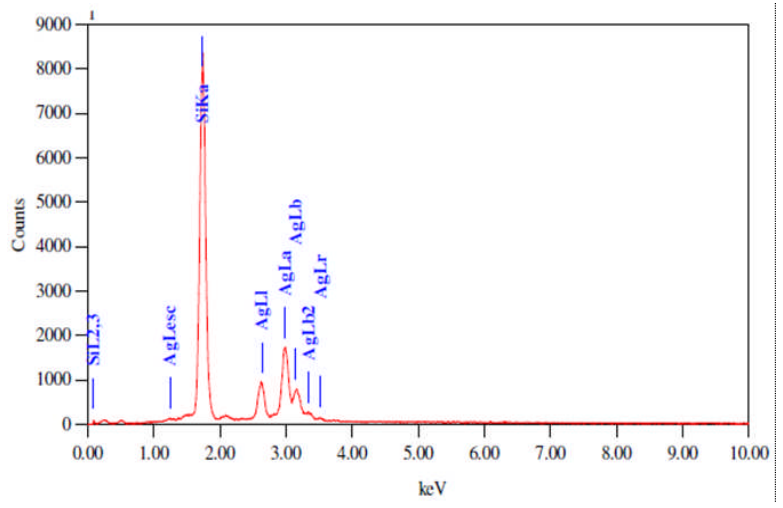

Gambar 6. Spektrum EDS senyawa nanopartikel perak hasil biosintesis menggunakan ekstrak Sambiloto. 


\section{Karakterisasi TEM}

Data karakterisasi TEM ditampilkan pada Gambar 7. Dengan skala pada gambar maka diperoleh ukuran dari senyawa nanopartikel perak hasil biosintesis tersebut adalah sekitar 10-30 $\mathrm{nm}$.

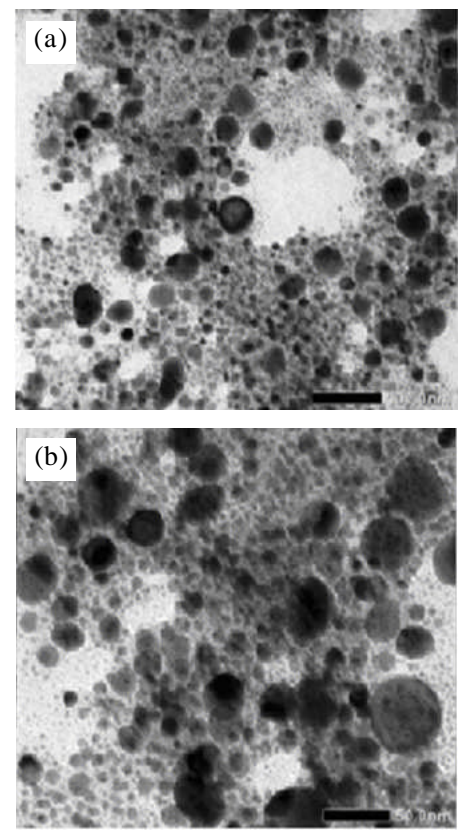

Gambar 7. Gambar TEM dari senyawa nanopartikel perak hasil biosintesis

\section{KESIMPULAN}

Dari hasil penelitian dapat disimpulkan bahwa daun Sambiloto dapat digunakan untuk mensintesis nanopatikel perak (AgNP). Rasio sintesis (larutan $\mathrm{AgNO}_{3}$ : larutan ekstrak Sambiloto) yang memberikan hasil optimal adalah $10 \mu \mathrm{L}: 10 \mathrm{~mL}$. Karakteristik nanopartikel perak yang diperoleh sebagai berikut. Absorbsi SPR diperoleh pada panjang gelombang di sekitar $423 \mathrm{~nm}$. Puncak-puncak difraksi teramati pada sudut 20:38,18 , $45,81^{\circ}$ dan $64,87^{\circ}$ bersesuaian dengan bidang hkl: (1 111$)$, (2 $\left.\begin{array}{lll}2 & 0\end{array}\right)$ dan (2 20 ), yang merupakan struktur kristal Face Centre Cubic dengan parameter kisi a adalah 4,03 ̊. Hasil karakterisasi dengan TEM diperoleh ukuran partikel sekitar 10-30 nm.

\section{DAFTAR ACUAN}

[1]. Guangquan Li, Dan He, Yongqing Qian, Buyuan Guan, Song Gao, Yan Cui, Koji Yokoyama and Li Wang. "Fungus-Mediated Green Synthesis of Silver Nanoparticles Using Aspergillus terreus," Int. J. Mol. Sci., vol. 13, pp. 466-476, 2012.

[2]. N Nyoman Rupiasih, Avinash Aher, Suresh Gosavi and P. B. Vidyasagar. "Green Synthesis of Silver Nanoparticles Using Latex Extract of Thevetia peruviana: a novel approach towards poisonous plant utilization." Journal of Physics: Conference Series, vol. 423 (012032), 2013.

[3]. Asmita J. Gavhane, P. Padmanabhan, Suresh P. Kamble and Suresh N. Jangle. "Synthesis of Silver Nanoparticles Using Extract of Neem Leaf and Triphala and Evaluation of Their Antimicrobial Activities.” Int. J. Pharm. Bio. Sci., vol. 3 (3), pp. 88-100, July 2012.

[4]. G. Alagumuthu and R. Kirubha. "Green Synthesis of Silver Nanoparticles Using Cissus Quadrangularis Plant Extract and Their Antibacterial Activity." International Journal of Nanomaterials and Biostructures, vol. 2 (3), pp. 30-33, 2012.

[5]. Windri Handayani. "Pemanfaatan Tumbuhan Tropis Untuk Biosintesis Nanopartikel Perak dan Aplikasinya Sebagai Indikator Kolometri Keberadaan Logam Berat." Thesis, Universitas Indonesia, 2011.

[6]. Cendranata WO. Daya Hambat Ekstrak Daun Sambiloto (Andrographis Paniculata) Terhadap Populasi Bakteri Pada Ulser Recurrent Aphthous Stomatitis. Jurnal PDGI, Vol. 61, No. 1, pp20-3. 2012

[7]. Bakir. "Pengembangan Biosintesis Nanopartikel Menggunakan Rebusan Daun Bisbul Untuk Deteksi Ion Tembaga Dengan Metode Kolorimetri," Thesis. Universitas Indonesia, 2011.

[8]. Herbert Chiguvare, Opeoluwa O. Oyedeji, Reuben Matewu, Olukayode Aremu, Idris A. Oyemitan, Adebola O. Oyedeji, Benedicta N. Nkeh-Chungag, Sandile P. Songca, Sneha Mohan and Oluwatobi S. Oluwafemi. "Synthesis of Silver Nanoparticles Using Buchu Plant Extracts and Their Analgesic Properties," Molecules, vol. 21 no 774, pp. 1-7. 2016.

[9]. Shakeel Ahmed, Mudasir Ahmad, Babu Lal Swami and Saiqa Ikram. "A review on Plants Extract Mediated Synthesis of Silver Nanoparticles for Antimicrobial Applications: A Green Expertise." Journal of Advanced Research, vol. 7, pp. 17-28. 2016.

[10]. Shakeel Ahmed and Saiqa Ikram. "Silver Nanoparticles: One Pot Green Synthesis Using Terminalia arjuna Extract for Biological Application," J. Nanomed. Nanotechnol, vol. 6, No. 4,pp. 1-6, 2015.

[11]. Is Fatimah. "Green Synthesis of Silver Nanoparticles Using Extract of Parkia Speciosa Hassk Pods Assisted by Microwave Irradiation." Journal of Advanced Research, vol. 7, pp. 961$969,2016$.

[12]. M. Thilagam, A. Tamiselvi, B. Chandrasekeran, C. Rose. "Photosynthesis of Silver Nanoparticles Using Medicinal and Dye Yielding Plant of Bixa Orellana L. Leaf extract.” JPSI, vol. 2, pp. 9-13, 2013 